\title{
ACCURACY OF IDIOM TRANSLATION IN SIDNEY SHELDON'S THE SKY IS FALLING INTO INDONESIAN LANGIT RUNTUH
}

\author{
Wulan Yulian Anggini \\ Program of Economics Education, Faculty of Education and Social Sciences, \\ University of Indraprasta PGRI \\ Jalan Nangka No. 58C Tanjung Barat, Jagakarsa, South Jakarta 12530 \\ angginiwulan10@gmail.com
}

\begin{abstract}
The purpose of this research is to know the accuracy of idiom translation and strategies that are used by the translator in translating the idiom into Bahasa Indonesia. This research uses qualitative descriptive analysis. After analyzing the results of accuracy of idiom translation from the three evaluators in the novel entitled The Sky is Falling, the researcher gets the conclusion that accuracy in " 0 " scale takes the highest position. There are three strategies used by the translator in translating idioms. They are paraphrase which marks $87 \%$, borrowing the source language idioms with $6 \%$, omission of entire idioms with $2 \%$, using an idiom of similar meaning but dissimilar form with $5 \%$.
\end{abstract}

Key words: accuracy, idiom translation, novel entitled The Sky is Falling

\section{ABSTRAK}

Tujuan dari penelitian adalah untuk mengetahui keakuratan dan kejelasan penerjemahan idiom dan strategi yang dipakai oleh penerjemah dalam menerjemahkan idiom ke dalam bahasa Indonesia. Metode penelitian yang digunakan untuk menganalisa novel ini melalui cara penelitian kualitatif deskriptif. Setelah peneliti menganalisa hasil keakuratan dan kejelasan penerjemahan idiom dari ketiga evaluator dalam novel yang berjudul The Sky is Falling, peneliti dapat menarik kesimpulan bahwa accuracy dengan skala "l" menempati posisi tertinggi. Ada empat strategi yang dipakai oleh penerjemah dalam menerjemahkan idiom. Mereka adalah paraphrase sebanyak $87 \%$, pungutan dari bahasa sumber sebanyak $6 \%$, penghilangan seluruh idiom sebanyak $2 \%$, dan penggunaan idiom arti sama dan bentuk berbeda sebanyak $5 \%$.

Kata kunci: akurasi, penerjemahan idiom, novel Langit Runtuh

\section{INTRODUCTION}

Translation is an important feature in a language development. It gives the people many kinds of information they need. Translation is the replacement of textual material in one language (Source Language) by equivalent textual material in another language (Target Language) (Catford,
1995). The language in which we are to translate is Source Language (SL) and the Target Language (TL) is our goal of translation. Readers can receive and understand the message from translation because the translators use equivalent language form. The important thing in translation is that translation must be natural without changing the meaning. 
In translating process, not only focus to translate a text literally, but also focus to adapt the SL culture into the TL culture. "Language is a part of culture and, therefore, translation from one language to another cannot be done adequately without knowledge of the two cultures as well as the two language structures" (Larson, 1984:431). A good illustration of culture similarity between English and Indonesian is baby shower or tujuh bulanan. Both traditions have the similar meaning, that is, a way to celebrate the pending or recent birth of a child. However, not every translator can translate the idiom of baby shower into tujuh bulanan. Only if he or she is familiar with both cultures, then he or she will be able to find the equivalence to translate this term. Unlike interpreting which is performed orally, translation activity is done on written form especially in the field of literary work such as novels. Nowadays when best seller foreign novels become popular in Indonesian marketing, usually local publishers have them translated into Indonesian. Here, the translators play their part.

One of the difficult things that arise in translating novel is idiom. Idiom often found in novels, because idiom is used in a wide variety of contexts and situations. Idiom is a group of words whose meaning is different from the meanings of the individual words. In idiom, sometimes the meaning is difficult to understand. It cannot get the meaning whether it is translated literally. In other words, the meaning of idiom is not the sum of the words taken individually.

Interpretation of the translators is very influential. There are many aspects that the translators have to completely pay attention. For the vast majority of text, translators have to pay attention to: 1) word order, 2) common structures, 3) cognate words, 4) the appropriateness of gerunds, infinitives, verb-nouns, 5) lexical uses, 6) the use of articles, progressive tenses, noun compounding, collocations, and currency of idioms and metaphors (Newmark, 1988). If the translators cannot pay careful attention into their work, there will be a mismatch in meaning from SL into TL.

Translating idioms are the most difficult task for the translators. The translators have to choose a proper strategy in translating idiom from SL to the TL. As a product, the translation has a level of quality. "A fine translation is the one who does not look like a translation" (Nida and Taber, 1982:12). It means that the result of translation is as natural as mother language of the target language. In order to create that, the translators need to apply some strategies. "The most important thing of a good translation is that it should be accurate, clear, and natural" (Larson, 1984:485). One point of views that decide whether translation has a certain quality or not, is an accuracy. In this case is the accuracy of idiom translation. A translation may be accurate in that the translator understood correctly the source text and is attempting to communicate that information, and it may even by understandable and yet the forms may not be the natural idiomatic forms of the receptor language (Larson, 1984:487).

Translators need to be convinced that in their translation are no additional, removal, or change information. It is not possible if the translators add, reduce, or eliminate important information. Some mistakes were made when analyzing the meaning of the SL in the process. Therefore, assessment of accuracy needs to be done.

On the basis of problems previously mentioned, the researcher 
decided to investigate the accuracy of idiom translation by using a good reference novel for idiom research novel. Thus, the title of this research is Accuracy of Idiom Translation in Sidney Sheldon's The Sky is Falling into Indonesian Langit Runtuh.

\section{METHOD}

This study applies qualitative approach in which the data were analyzed by explaining descriptively. According to Wolcott as citied in Creswell, 2009:182), conveys that "Qualitative research is fundamentally interpretive". The researcher describes the phenomena of idioms and their translation in the novel entitled The Sky is Falling which was translated by Hidayat under the licensed of Gramedia Pustaka Utama Publishing Company.

The data were collected through some steps: 1) close reading, since this study is a library research. These were done in order to find out the occurrence of the english idioms occur in the novel The Sky is Falling by Sheldon (2000), 2) note taking the occurrence of idioms in the SL text, 3) finding out the translation of the english idioms in the translated novel Langit Runtuh by Saleh (2001) which was used in the TL, 4) comparing the SL into the TL, and 5) finding the accuracy and by using IAS scales that proposed by Nagao (1986) in the form of questionnaire which are filled by three evaluators.

The population of this research is all of text from page three until page three hundred fourteen which existing in the novel entitled The Sky is Falling. The sample is the first one hundred idioms divided into three types: nominal combinations, phrasal verb idioms, torture idioms, and phraseological idioms of encoding.

In this study, the researcher plays role as the research instrument.
The researcher acts as the planner, the data collector, the data analyst, and the reporter of research result. The main data of this research is the English version novel and Indonesian version novel. The researcher finds the idioms in both languages. After that, classified them and write them down on data sheets.

To get the data validity, the researcher classifies the main data based on type of idioms which is purposed by (Makkai, 2011). The main data are processed into rating of questionnaire and they are reobserved by dividing each percentage based on idioms' classification. The last is drawing conclusion which showed by descriptive way.

\section{RESULTS AND DISCUSSION \\ The Description of Research Information}

Accuracy of Idioms Translation in Sidney Sheldon's The Sky is Falling into Indonesian Langit Runtuh is a qualitative descriptive analysis research. The idioms are taken, grouped, and researched based on Makkai's Idiom Structure in English. These idioms are identified and observed their translation into TL. The researcher uses this novel because this novel is avaliable both in English and Indonesian version. This novel is written by Sheldon, an Academy Award-winning American writer who won an Oscar in 1948.

\section{The Description of Data Findings 1. Data Findings}

There are first one hundred idioms that can be found by the researcher from the novel entintled The Sky is Falling. These idioms include nominal combinations, phrasal verb idioms, tournure idioms, and phraseological idioms of encoding.

\section{Data Classification}




\section{a. Nominal Combination}

In the type of nominal combinations, we find the type of idioms that use the nominal phrase. As the example in the word protean lover is considered as nominal combination, protean literally means able to change quickly and easily and lovers stands as a noun which describing person who loves something. However, protean lover stands as idiom that mean berpengalaman di atas ranjang.

Table 1

Nominal Combinations

\begin{tabular}{|c|c|c|}
\hline English & Indonesian & $\begin{array}{c}\text { Translation } \\
\text { Strategy }\end{array}$ \\
\hline White House & Gedung Putih & $\begin{array}{l}\text { using an idiom of } \\
\text { similar meaning but } \\
\text { dissimilar form }\end{array}$ \\
\hline $\begin{array}{l}\text { a striking } \\
\text { couple }\end{array}$ & $\begin{array}{l}\text { pasangan yang } \\
\text { mempesona }\end{array}$ & $\begin{array}{l}\text { using an idiom of } \\
\text { similar meaning but } \\
\text { dissimilar form }\end{array}$ \\
\hline $\begin{array}{l}\text { bitch } \\
\text { stepmother }\end{array}$ & ibu angkat yang busuk & paraphrase \\
\hline goddamn wars & perang terkutuk & paraphrase \\
\hline $\begin{array}{l}\text { a bastard } \\
\text { search }\end{array}$ & bastard search & $\begin{array}{l}\text { borrowing the } \\
\text { source language } \\
\text { idiom }\end{array}$ \\
\hline $\begin{array}{l}\text { cold stell-gray } \\
\text { eyes }\end{array}$ & $\begin{array}{l}\text { mata kelabu baja yang } \\
\text { dingin }\end{array}$ & $\begin{array}{l}\text { using an idiom of } \\
\text { similar meaning but } \\
\text { dissimilar form }\end{array}$ \\
\hline big time & orang besar & paraphrase \\
\hline Total & 7 & \\
\hline
\end{tabular}

\section{b. Phrasal Verb Idioms}

The idioms that employs verb and preposition to bear new meaning. There are 63 phrasal verbs in the table. The researcher takes wearing out as one of the examples. This idiom cannot be translated word by word yet. The whole words generate one meaning, as wearing out means kehabisan tenaga.

Table 2

Phrasal Verb Idioms

\begin{tabular}{lll}
\hline \multicolumn{1}{c}{ English } & \multicolumn{1}{c}{ Indonesian } & Translation Strategy \\
\hline $\begin{array}{l}\text { laid-back } \\
\text { follow-up }\end{array}$ & $\begin{array}{l}\text { Santai } \\
\text { follow-up }\end{array}$ & $\begin{array}{l}\text { paraphrase } \\
\text { borrowing the source } \\
\text { language idiom } \\
\text { paraphrase }\end{array}$ \\
coming up & Masih & paraphrase \\
pulled back & di tarik mundur & paraphrase \\
stepped out & Melangkah & paraphrase \\
sit up & Duduk & paraphrase \\
picked up & Mengangkat & paraphrase \\
get rid of & Menyingkirkan & paraphrase \\
bustling up & Menghampirii & paraphrase \\
lit up & jadi berseri & paraphrase \\
brightened up & Mempercerah & paraphrase \\
come out & Dating & \\
\hline
\end{tabular}




\begin{tabular}{|c|c|c|}
\hline went on & - & $\begin{array}{l}\text { omission of entire } \\
\text { idiom }\end{array}$ \\
\hline taking care & Mengurus & paraphrase \\
\hline move on & terus berjalan & paraphrase \\
\hline taken away & dibawa pulang & paraphrase \\
\hline get hold of & mendapatkannya & paraphrase \\
\hline kick out & mendepakmu & paraphrase \\
\hline get back & kembali & paraphrase \\
\hline warming up & - & $\begin{array}{l}\text { omission of entire } \\
\text { idiom }\end{array}$ \\
\hline took out & mengeluarkan & paraphrase \\
\hline zip up & menutup resleting & paraphrase \\
\hline give up & menyerah & paraphrase \\
\hline break-in & pengrusakan & paraphrase \\
\hline carried on & meneruskan & paraphrase \\
\hline closed off & ditutup & paraphrase \\
\hline right back & kembali & paraphrase \\
\hline burned-out & terbakar habis & paraphrase \\
\hline skidded off & tergelincir & paraphrase \\
\hline bundled-up & dalam pakaian & paraphrase \\
\hline turned off & mematikan & paraphrase \\
\hline took up & naik & paraphrase \\
\hline tear down & menghancurkan & paraphrase \\
\hline strode out & berjalan cepat keluar & paraphrase \\
\hline turn away & berbalik & paraphrase \\
\hline held up & mengangkat & paraphrase \\
\hline going on & berlangsung & paraphrase \\
\hline cover up & kedok & paraphrase \\
\hline find out & selidiki & paraphrase \\
\hline got up & berdiri & paraphrase \\
\hline dropped off & mengantar & paraphrase \\
\hline put on & memakai & paraphrase \\
\hline put up & mentolerir & paraphrase \\
\hline looked up & mencari & paraphrase \\
\hline gotten away & lolos & paraphrase \\
\hline tied up & tertahan & paraphrase \\
\hline set up & didirikan & paraphrase \\
\hline hung up & $\begin{array}{l}\text { memutuskan } \\
\text { percakapan telepon }\end{array}$ & paraphrase \\
\hline makeup & makeup & $\begin{array}{l}\text { borrowing the source } \\
\text { language idiom }\end{array}$ \\
\hline took care & $\begin{array}{l}\text { sudah } \\
\text { membereskannya }\end{array}$ & paraphrase \\
\hline draw out & mengambil & paraphrase \\
\hline let out & menghembuskan & paraphrase \\
\hline took place & dilakukan & paraphrase \\
\hline mix-up & kekeliruan & paraphrase \\
\hline wearing-out & menguras tenaga & paraphrase \\
\hline wiped out & letih & paraphrase \\
\hline fix up & memberi & paraphrase \\
\hline put on airs & congkak & paraphrase \\
\hline logged on & $\log$ on & $\begin{array}{l}\text { borrowing the source } \\
\text { language idiom }\end{array}$ \\
\hline make up & memutuskan & paraphrase \\
\hline run-down & reyot & paraphrase \\
\hline beat-up & butut & paraphrase \\
\hline sink in & mencerna & paraphrase \\
\hline Total & 63 & \\
\hline
\end{tabular}




\section{c. Tournure Idioms}

A tournure is a lexemic idiom consisting of at least three lexons and optionally containing the definite article the or indefinite article a/an.

Table 3

Tournure Idioms

\begin{tabular}{lll}
\hline \multicolumn{1}{c}{ English } & Indonesian & $\begin{array}{c}\text { Translation } \\
\text { Strategy }\end{array}$ \\
\hline $\begin{array}{l}\text { to be a } \\
\text { nightmare } \\
\text { of alphabet }\end{array}$ & $\begin{array}{l}\text { bagai menjadi } \\
\text { mimpi buruk } \\
\text { tumpukan }\end{array}$ & paraphrase \\
$\begin{array}{l}\text { soup dig up } \\
\text { skeletons }\end{array}$ & $\begin{array}{l}\text { abjad } \\
\text { mengorek aib }\end{array}$ & paraphrase \\
\hline Total & & $\mathbf{2}$ \\
\hline
\end{tabular}

\section{d. Phraseological Idioms of Encoding}

The idioms based on the set pattern which the meaning is definitely familiar when the first people hear. The people do not wonder and feel obscure toward the words and its meaning. As in the table mind racing does not mean balapan pikiran translated word by word yet the whole meaning, based on the set pattern is memutar otak which contrary to the word by word meaning.

Table 4

Phraseological Idioms of Encoding

\begin{tabular}{|c|c|c|}
\hline English & Indonesian & $\begin{array}{c}\text { Translation } \\
\text { Strategy }\end{array}$ \\
\hline on-air & on-air & $\begin{array}{l}\text { borrowing the source } \\
\text { language idiom }\end{array}$ \\
\hline world-famous & $\begin{array}{l}\text { terkenal diseluruh } \\
\text { dunia }\end{array}$ & $\begin{array}{l}\text { using an idiom of } \\
\text { similar meaning but } \\
\text { dissimilar form }\end{array}$ \\
\hline middle-age & setengah baya & paraphrase \\
\hline mind racing & pikiran berputar cepat & paraphrase \\
\hline heart racing & jantung berdebar-debar & paraphrase \\
\hline walk in his shoes & $\begin{array}{l}\text { coba berada pada } \\
\text { posisinya }\end{array}$ & paraphrase \\
\hline ill-fated & bernasib malang & paraphrase \\
\hline shaking hand & berjabat tangan & paraphrase \\
\hline off the record & off the record & $\begin{array}{l}\text { borrowing the source } \\
\text { language idiom }\end{array}$ \\
\hline well-known & terkenal & paraphrase \\
\hline $\begin{array}{l}\text { street-smart } \\
\text { misanthrope }\end{array}$ & $\begin{array}{l}\text { polisi berpengalan } \\
\text { yang suka bergaul }\end{array}$ & paraphrase \\
\hline $\begin{array}{l}\text { Chicken Little } \\
\text { conspiracy }\end{array}$ & konspirasi sinting & paraphrase \\
\hline far-fetched & mengada-ngada & paraphrase \\
\hline pretty prickly & menyengat & paraphrase \\
\hline keep in touch & kirim kabar & paraphrase \\
\hline no-show & tidak akan datang & paraphrase \\
\hline play stinky finger & main-main & paraphrase \\
\hline a great deal & banyak artikel & paraphrase \\
\hline holier-than-thou & munafik & paraphrase \\
\hline black-tie-affair & bersuasana resmi & paraphrase \\
\hline the name dropping & daftar nama & paraphrase \\
\hline off-camera & $\begin{array}{l}\text { diluar jangkauan } \\
\text { kamera }\end{array}$ & paraphrase \\
\hline
\end{tabular}




\begin{tabular}{lll}
\hline cold-bloodedly & darah dingin & $\begin{array}{l}\text { using an idiom of } \\
\text { similar meaning but } \\
\text { dissimilar form } \\
\text { paraphrase } \\
\text { paraphrase }\end{array}$ \\
$\begin{array}{l}\text { down-to-earth } \\
\text { sight-seeing }\end{array}$ & $\begin{array}{l}\text { rendah hati } \\
\text { melancong }\end{array}$ & paraphrase \\
$\begin{array}{l}\text { a nervous } \\
\text { breakdown } \\
\begin{array}{l}\text { a hit-and-run } \\
\text { driver }\end{array}\end{array}$ & Gila \\
$\begin{array}{l}\text { on some wild- } \\
\text { goose chase }\end{array}$ & $\begin{array}{l}\text { mengejar jejak yang } \\
\text { tak tentu arah }\end{array}$ & paraphrase \\
\hline Total & $\mathbf{2 7}$ & paraphrase \\
\hline
\end{tabular}

\section{Interpretation}

\section{Types of Idioms}

There are one hundred idioms that the researcher can identify in this research. They are grouped into four types. They are nominal combinations, phrasal verb idioms, tournure idioms and phraseological idioms of encoding. Many idioms are in the form of phrasal verb idioms since it takes sixty three numbers out of one hundred. Meanwhile, at least with only two data found in tournure idioms. These findings show us that phrasal verbs idioms are the most common of idioms that the novel writer's using. To make clear, the distribution of each type of idioms is described in the pie chart below.

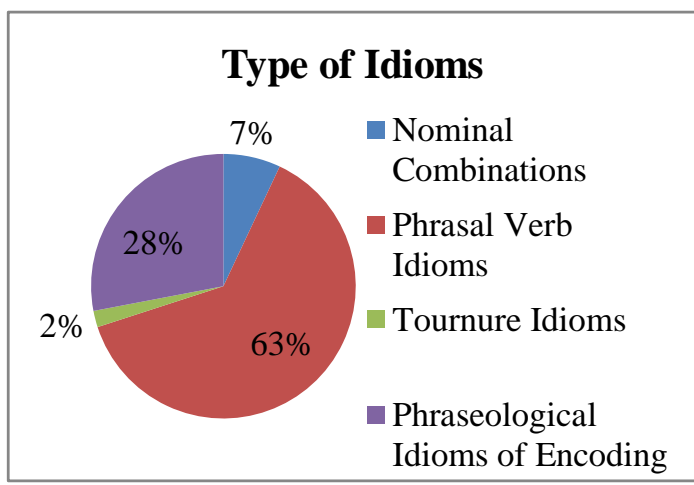

Figure 1. Types of Idioms

\section{Translation Strategy}

There are four strategies of translation used by the translator in translating idioms in this research.
They are paraphrase, borrowing the source language idioms, omission of entire idiom, and using the idiom of similar meaning but dissimilar form. The distribution of the type of translation is shown in the pie chart below.

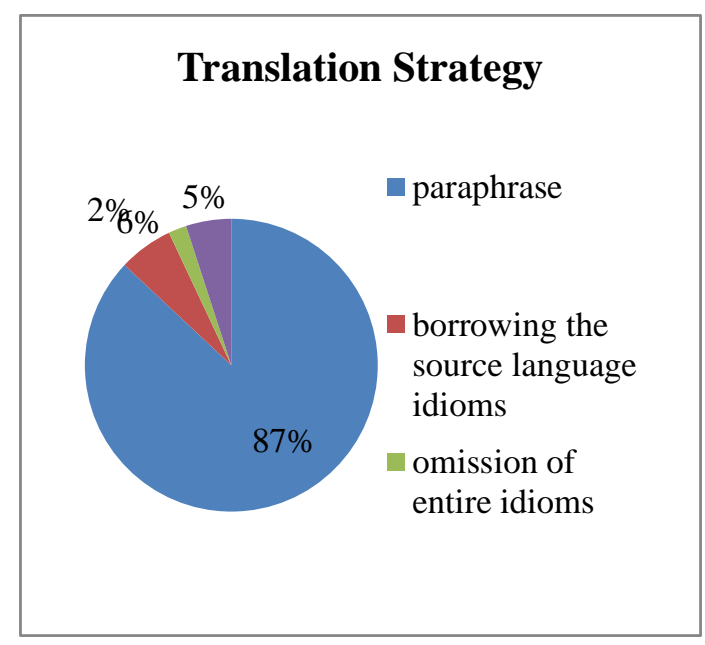

Figure 2. Translation Strategy

\section{Accuracy Scale}

The Accuracy scale provides an evaluation of the degree to which the translated text conveys the meaning of the original text as well as a measure of the amount of difference between the input and the output texts. Accuracy is measured on a scale from zero to six as follows:

1. The content of the input text is faithfully conveyed to the output text. The translated text would be 
clear to a native French speaker and no writing is needed.

2. The content of the input text is faithfully conveyed to the output text, and could be clearly understood by a native French speaker, but some rewriting is needed. The text could be corrected by a native French speaker without referring to the original text. No English language assistance would be required.

3. The content of the text is faithfully conveyed to the output text, but between phrases and expressions, and with tense, voice, plurals, and the position of adverbs.

4. The content of the input text is not adequately conveyed to the output text. Some expressions are missing, and there are problems with the relationships between clauses, phrases, and clauses, or sentence elements.

5. The content of the text is not conveyed to the output text. Clauses and phrases are missing.

6. The content of the input text is not conveyed at all. The output contains improper sentences; subjects and predicates are missing. In noun phrases, the head noun is missing, or a clause or phrases acting as a verb and modifying a noun is missing some changes are needed in word order, Nagao (1986).

While the content of the input text is generally conveyed faithfully to the output text, there are some problems with things like relationships

\section{Evaluator 1}

At the stage of accuracy which the translated text delivers the meaning of the original text to the TL text is retained or between the input and output text would not be any difference in meaning.
The evaluation sheets of accuracy denounce " 0 " scale attains $58 \%$, the idioms translation result is perfectly clear and the input and output text are definitely conveyed. $0 \%$ scale shows the lowest accuracy score that between the input and output text are not conveyed well.

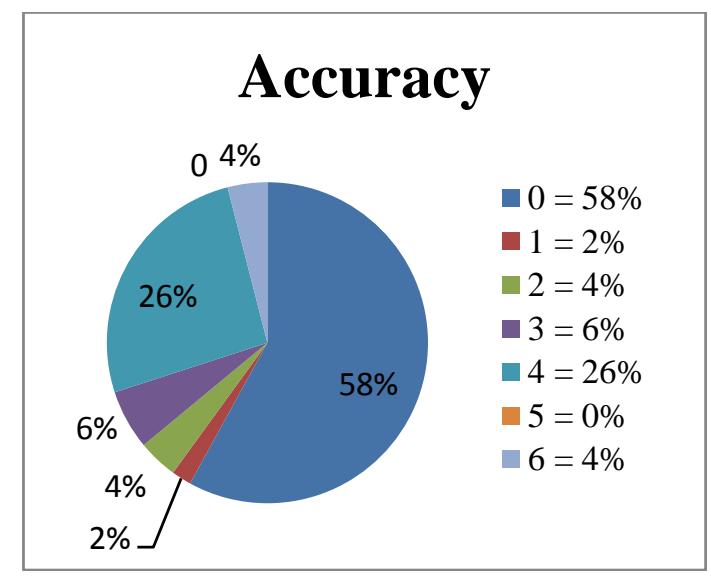

\section{Evaluator 2}

In the second evaluator, the input of words translated is definitely conveyed and clear to the output of words translated " 0 " scale is $60 \%$. The lowest percentage is $0 \%$ occurs in the first and third scale that input of the words translated is conveyed to the output ones, problems might occur in phrases, expressions, plurals, and position of adverb.

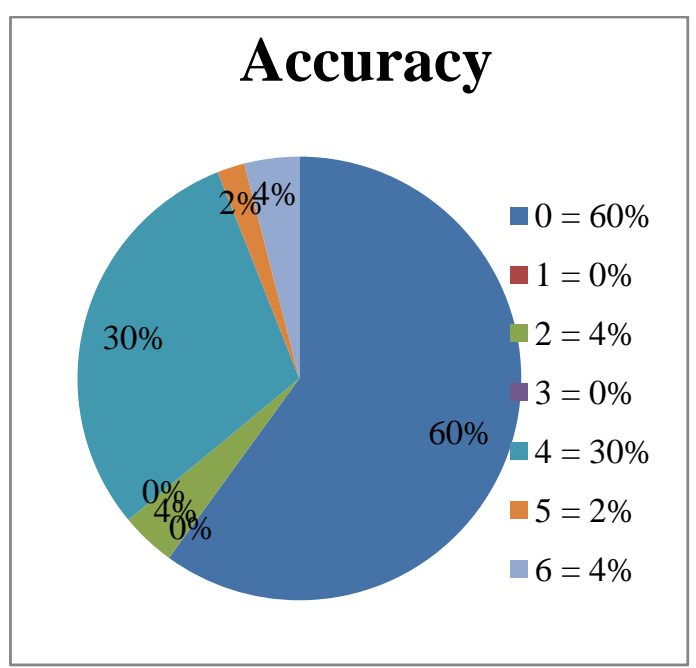




\section{Evaluator 3}

$52 \%$ occurs in " 0 " scale of accuracy that the entirely input and output of words translated is successfully conveyed and clear. The lowest score is $0 \%$ in the forth and the last scale. The forth refers to the input of words translated is sufficiently conveyed. There might be some expressions missing, problems with clauses, and phrases. The last scale occurs because the whole input and output is not conveyed at all. There are subject and predicates missing, head noun missing, verb and modifying noun missing.

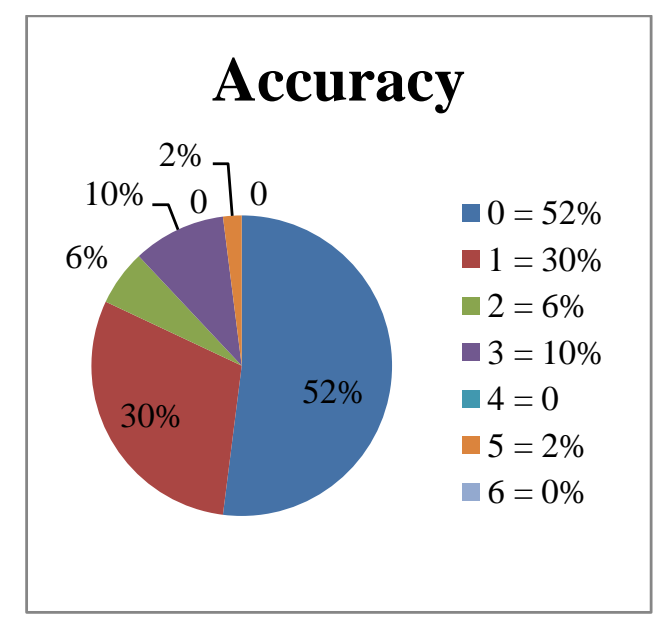

\section{CONCLUSION}

After analyzing the data related to the translation of idioms in the novel The Sky is Falling into Langit Runtuh, there are some conclusions can be made as follows:

1. Based on the research done, the researcher concludes that most of the scale of all evaluators from accuracy scale is " 0 ", which shows between the input and output of words translated is completely conveyed. The idioms translation is accurate.

2. From one hundred idioms that the researcher found in the novel entitled The Sky is Falling, 87\% idioms are translated by using paraphrase strategy. Paraphrasing is the strategy which is usually common to employ in cultural text to preserve the meaning.

\section{REFERENCES}

Catford, J. (1995). A Linguistic Theory of Translation. London: Oxford University Press.

Creswell, J. W. (2009). Research Design: Qualitative, Quantitative, and Mixed Method Approach. London: SAGE Publications.

Larson, M. (1984). Meaning Based Translation. Boston: Summer Institute of Linguistics.

Makkai, A. (2011). Idiom Structure in English. Mouton: The Hague.

Nagao, M. (1986). Machine Translation from Japanese to English. Tokyo: Proceedings of the IEEF

Newmark, P. (1988). A Textbook of Translation. New York: Prentice Hall.

Nida, E. A., \& Taber, C. R. (1982). The Theory and Practice of Translation. Leiden: E. J. Brill.

Saleh, H. (2001). Langit Runtuh. Jakarta: Gramedia Pustaka Utama.

Sheldon, S. (2000). The Sky is Falling. Great Britain: Harper Collins Publisher.. 